\title{
Leading agritourism facilities along Nearly Zero Energy paths: proposal of an easy-to-use evaluation method
}

\author{
Laura Cirrincione ${ }^{1,2, *}$, Giorgia Peri ${ }^{1}$, Gianfranco Rizzo ${ }^{1}$, and Gianluca Scaccianoce ${ }^{1,3}$ \\ ${ }^{1}$ Department of Engineering, University of Palermo, Viale delle Scienze Bld. 9 Palermo, Italy \\ ${ }^{2}$ Luxembourg Institute of Science and Technology (LIST), Environmental Research \& Innovation \\ Department (ERIN), 41, rue du Brill, L-4422 Belvaux (Sanem), Luxembourg \\ ${ }^{3}$ National Research Council of Italy, Institute of Biomedicine and Molecular Immunology, via Ugo \\ La Malfa 153, 90146 Palermo, Italy
}

\begin{abstract}
The tourist sector, despite the present severe constraints imposed by the sanitary emergence, can be considered as an important component of almost all countries' economies. In Italy agriturism, in particular, has been experiences a continuously rising trend in recent years. Clearly, such great interest towards these businesses also calls for a deep attention by an energy point of view, in sight of an energy efficiency improvement, hence a lowering of the pressure that such facilities exert to the natural environment. On the other hand, the European Union has been engaged, for a long time, in awarding the tourist accommodations environmental excellence brands, like the EU Ecolabel. Unfortunately, the achievement of such excellence brands requires the capability of managing complex energy and environmental data, which is often not the prerogative of people running such facilities. In order of contributing to overcome this difficulty, and with the aim of helping the addressing of agritourism towards a Nearly Zero Energy path, we propose here a simple approach that does not require the modelling and simulation of the energy behaviour of an agritourism, being essentially based on the application of easy-to-use ARERA (Italian Regulatory Authority for Energy Networks and Environment) datasheets scheme. On purpose, an application of the method, involving two typical Sicilian agritourism, is presented. The obtained results showed the viability of the proposed methodology, although the need of an update and/or replacement of some technical datasheets arose.
\end{abstract}

\section{Introduction}

The tourist sector, despite the presently existent severe constraints imposed by the sanitary emergence, interests almost all the countries and must be considered as an important component of the world's economies, accounting for approximately $10 \%$ of total global gross domestic product (GDP), $7 \%$ of global trade and $11 \%$ of the world's

\footnotetext{
*Corresponding author: laura.cirrincione@unipa.it
} 
employment [1, 2], with a continuously rising trend [3, 4]. Accordingly, tourism represent an important contributor to energy consumption both at global and European scale [5, 6, 7], most of which is consumed in space heating and/or air conditioning (up to 50\%), followed by hot water and cooking [8,9]. Hence, tourism exercises a relevant impact on the environment, being responsible for about $5 \%$ of the global $\mathrm{CO} 2$ amount emitted by human activities [1, 10]. Consequently, in recent years much effort has been put, at global [11, 12], European [13, 14] and national [15] level, into implementing a series of energy and environmental policies in order to achieve a more sustainable tourism [16, 17].

In Italy, in particular, tourism's positive growth trend is even more evident; in the year 2017, the tourism sector accounted for a share of $13.2 \%$ of the total domestic GDP, which reflected in $14.9 \%$ share of the country's total employment [18], representing one of the fastest growing industry in the country. That is why, public and private business organizations, both at national and regional level, are strongly interested in tourism's economic and environmental impact $[19,20]$.

Within this context, agritourism, especially in Italy, is traditionally selected by people, being a particular sustainable form of tourism by means of which travellers may directly experience the excellences that the local territory could offer, thanks to its biodiversity, rural landscapes, gastronomic products, and at the same time encouraging the use of green practices in order to maintain the local historical and natural settings [10, 21].

Clearly, such great interest towards the high number of agritourism sites in Italy also calls for a deep attention by an energy point of view, in sight of an improvement of their efficiency that, obviously, may result in a lowering of the pressure that such facilities exert to the natural environment. In fact, in recent years such matter has been of interest to the academic world, where studies concerning the economic and social benefits of the various tourist activities in the rural area, including agritourism [22, 23], and their environmental performance in terms of energy performance [24, 25, 26], can be found.

On the other hand, as previously mentioned, the European Union has been engaged, for a long time, in providing the tourism sector with environmental management practice regulations $[27,28]$ and awarding the tourist accommodations by excellence bands that constitute an important mean of communication towards visitors that, with a rising tendency, select their vacation destinations having in mind an environmental consciousness perspective. In this regard, one of the most recognizable brands is the EU Ecolabel for Tourist Accommodation Services [29], created to improve the environmental performance of such structures, by providing efficient guidelines on the suitable action to decrease their environmental impact.

Unfortunately, the achievement of such excellence brands by the agritourism sites requires the capability of managing complex energy and environmental data; this skill is regrettably not often at the availability of people that usually own and/or run such facilities.

In order of contributing to overcome this difficulty, we propose here a simple approach that does not require the modelling and simulation of the energy behaviour of an agritourism, being essentially based on the application of easy-to-use datasheets, that is the ARERA (Italian Regulatory Authority for Energy Networks and Environment) scheme [30] originally issued for the urban residential building stock, which allow the assessment of the energy and the environmental benefits related to the implementation of energy efficiency interventions on a given premise.

The objective of this proposal is twofold. On one hand, helping the addressing of agritourism towards a Nearly Zero Energy path, which involves relevant economic and environmental performances, as parallelism with the well-known EU Nearly Zero-Energy Buildings (nZEB) and Nearly Zero-Energy Hotels (nZEH) [31-34] projects. On the other hand, helping the addressing of these facilities along a virtuous path leading to the possible achievement of a European environmental excellence brand, like the EU Ecolabel [29]. On 
purpose, an application of the method is presented, involving a couple of typical Sicilian agritourisms, in order of assessing its feasibility and with the aim of discussing its possible applicability to the whole (Sicilian) agritourism building stock.

\section{Materials and Methods}

According to the Italian national [35] and the Sicilian regional [36, 37] legislation agritourism are businesses providing accommodation and catering services using mainly products of own and/or local production, and possibly organizing recreational and cultural activities aimed at enhancing the territory peculiarities.

The adoption of an environmental brand, like the Ecolabel for Tourist Accommodation Services [29], can therefore represent an advantage both for agritourisms' owners and for the entire territory, since it can be seen as a mean able to shifting tourism's attention from the urban context towards rural settings, by legitimizing the accommodations' efforts in reducing their environmental impacts.

The Ecolabel for Tourist Accommodation Services [29] is part of the widely recognized EU Ecolabel brand (Figure 1), established at the beginning of the '90s by the European Union, and actually regulated by Regulation (EC) n. 66/2010 [38], as a voluntary environmental performance certificate that is awarded to products and services that consume less energy and generate less waste and $\mathrm{CO}_{2}$ emissions.

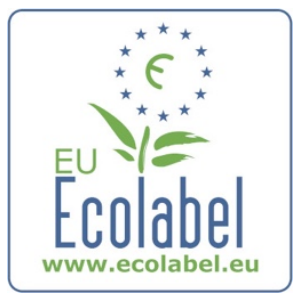

Fig. 1. EU Ecolabel logo [39].

The EU Ecolabel for Tourist Accommodation Services, in particular, establishes a set of criteria on the action that such specific structures can put in practice to improve their environmental performance. The provided criteria comprise the five categories of general management, energy, water, waste and other, and are divided in mandatory and optional. In order to obtain the EU Ecolabel brand, an accommodation service has to observe all the applicable mandatory criteria and receive a minimum of twenty points for the optional criteria [29]. For the purpose of this paper only the energy criteria, shown in Table 1, have been considered.

Table 1. Energy Criteria established by the EU Ecolabel for Tourist Accommodation Services.

\begin{tabular}{c|ll}
\hline \multicolumn{3}{c}{ EU Ecolabel for Tourist Accommodation Services Energy Criteria } \\
\hline & $\mathbf{N}^{\circ}$ & \multicolumn{1}{c}{ Proposed intervention } \\
\cline { 2 - 3 } & 6 & Energy efficient space heating and water heating appliances \\
7 & Energy efficient air conditioning and air-based heat pumps appliances \\
\hline \multirow{2}{*}{} & 8 & Energy efficient lighting \\
9 & Thermoregulation \\
10 & Automatic switching off of HVAC and lighting \\
11 & Outside heating and air conditioning appliances
\end{tabular}


12 Procurement of electricity from a renewable electricity supplier

13 Coal and heating oils :

28 Energy efficient space heating and water heating appliances (up to 3 points)

29 Energy efficient air conditioning and air-based heat pumps appliances (up to 3,5 points)

30 Air-based heat pumps up to $100 \mathrm{~kW}$ heat output (3 points)

31 Energy efficient household appliances and lighting (up to 4 points)

32 Heat recovery (up to 3 points)

33 Thermoregulation and window insulation (up to 4 points)

34 Automatic switch off appliances/devices (up to 4,5 points)

35 District heating/cooling and cooling from cogeneration (up to 4 points)

36 Electric hand driers with proximity sensor (1 point)

37 Space Heater emissions (1,5 points)

38 Procurement of electricity from a renewable electricity supplier (up to 4 points)

39 On site self-generation of electricity through renewable energy sources (up to 5 points)

40 Heating energy from renewable energy sources (up to 3,5 points)

41 Swimming pool heating (up to 1,5 points)

The Italian Regulatory Authority for Energy Networks and Environment - ARERA is an independent body that deals with promoting the adoption of specific interventions in order to achieve a more sustainable and rational use of energy, by either increasing energy efficiency or promoting energy saving. The work of ARERA involves different sectors, such as the use of electricity and natural gas, water services, district heating and cooling, and waste and wastewater management [30].

As previously mentioned, the purpose of this paper is investigating the possibility of using the computational scheme proposed by the ARERA to estimate the increase in energy efficiency consequent to the implementation of some of the EU Ecolabel proposed intervention. Thus, only the data sheets regarding the energy savings measures that could be transferred and applied to agritourism structures have been taken into account, as reported in Table 2.

Table 2. List of the standardized and analytical technical data sheets for the evaluation of energy savings.

ARERA Technical Data Sheets

\begin{tabular}{cc}
$\mathbf{N}^{\circ}$ & Proposed Intervention \\
\hline 5 & Replacement of simple glazing with double glazing \\
7 & Use of photovoltaic systems with an electrical power of less than $20 \mathrm{~kW}$ \\
$8 \mathrm{~T}$ & Installation of solar collectors for the production of domestic hot water \\
15 & Installation of outdoor air electric heat pumps instead of boilers in newly built or renovated residential \\
$\mathrm{T}$ & buildings \\
19 & Installation of high efficiency outdoor air conditioners with cooling capacity lower than $12 \mathrm{kWf}$ \\
$\mathrm{T}$ & Installation of electric heat pump for domestic hot water production in new and existing plants \\
27 & \\
\hline
\end{tabular}


Regarding the energy savings category, the proposed interventions are provided by means of technical data sheets indicating the calculation procedures that allow to obtain reduction rates of primary energy consumption actually achieved, expressed in toe (tons of oil equivalent), which may also be used for the issuing energy efficiency certificates [30].

In order to show the proposed approach, as an example, it was decided to report here the application of one of the technical data sheets listed in Table 2, that is $\mathrm{N}^{\circ} 7$ ("Use of photovoltaic systems with an electrical power of less than $20 \mathrm{~kW}$ "), as it should be one of those allowing to obtain the greatest energy savings. In this case, according to the ARERA calculation procedure [30], the achievable specific gross primary energy savings $(R S L)$, for each reference physical unit $(U F R)$, are given by the following equation:

$$
R S L=k W_{p} \times h_{e q} \times k 1 \times 0.22 \cdot 10^{-3} \text { [toe/year] }
$$

where:

- UFR represent a photovoltaic system with electrical power $<20 \mathrm{~kW}$;

- $k W_{p}$ is the peak power of the system, expressed in $\mathrm{kW}$;

- $h_{e q}$ is a coefficient dependent on the solar belt and the province considered, expressed in $\mathrm{h} /$ year;

- $k_{I}$ is a dimensionless coefficient that varies in function of the inclination $(\beta)$ of the photovoltaic modules on to the horizontal plane, that is $k_{1}=0,70$ for $\beta>70^{\circ}$, otherwise $k_{l}=1$;

- $0.22 \cdot 10^{-3}$ is a conversion factor.

For the purpose of estimating the possible energy savings within a real context, the consumption of two agritourisms located in the Sicilian province of Palermo (Italy), was taken into account, obtained by surveys and interviews with the owners of these structures. Specifically, the two agritourisms are Villa Dafne (sited in the small town of Alia) and Bergi (sited in the small town of Castelbuono); such structures are to be considered representative of the regional agritourism landscape, both as regards their size and the services provided, and, therefore, also for what concerns the energy consumption.

Initially, based on the obtained information, the data regarding the energy consumption were broken down into percentages, and corresponding toe/year, according to four main categories, as shown in Table 3.

Table 3. Energy consumption percentage distribution for the two considered agritourisms.

\begin{tabular}{|c|c|c|c|c|c|}
\hline \multirow{2}{*}{ Energy consumption category } & \multirow{2}{*}{ Energy source } & \multicolumn{2}{|c|}{ Villa Dafne } & \multicolumn{2}{|c|}{ Bergi } \\
\hline & & $\%$ & toe/year & $\%$ & toe/year \\
\hline \multirow{2}{*}{ Domestic Hot Water (DHW) } & gas & 0 & 0.00 & 16 & 5.09 \\
\hline & electricity & 22 & 9.72 & 6 & 1.91 \\
\hline Lighting & electricity & 15 & 6.63 & 15 & 4.74 \\
\hline \multirow{2}{*}{$\begin{array}{l}\text { Heating, Ventilation and Air } \\
\text { Conditioning (HVAC) }\end{array}$} & gas & 25 & 11.05 & 15 & 4.74 \\
\hline & electricity & 14 & 6.19 & 24 & 7.64 \\
\hline \multirow{3}{*}{ Other } & gas & 0 & 0.00 & 0 & 0.00 \\
\hline & electricity & 24 & 10.60 & 24 & 7.64 \\
\hline & Total & & 44.18 & & 31.82 \\
\hline
\end{tabular}


Successively, the RSL, calculated through equation (1), was compared to the consumption categories reported in Table 3 by means of equation (2), in order to obtain the possible energy savings $(E S)$ in terms of percentage of electricity consumption covered by the proposed intervention (data sheet $\mathrm{N}^{\circ} 7$ ) on annual basis.

$$
E S=R S L /(D H W+H V A C+\text { Lighting }+ \text { Other })[\%]
$$

\section{Results and Discussion}

In this section the outcomes of the application of technical data sheets $\mathrm{N}^{\circ} 7$ to the energy consumption of the considered agritourisms are reported.

Regarding the parameters to insert in equation (1), since ARERA imposes a limit on the UFR size, it was chosen to set a value of $19.9 \mathrm{~kW}$ as peak power of the system $\left(k W_{p}\right)$, in order to make the most of the proposed intervention potential; while, the $h_{e q}$ suggested value for the province of Palermo results, being $1852 \mathrm{~h} /$ year. As for $k_{l}$, instead, this was set equal to 1 . In this way a $R S L$ value of 8.1 toe/year was obtained.

As reported in the previous paragraph, once the $R S L$ was obtained, this was compared to the real consumptions of the two agritourisms using equation (2), therefore considering the shares of consumption categories (Table 3 ) related to the electricity energy source. It was, thus, possible to obtain the achievable energy savings $E S$ shown in Figure 2.

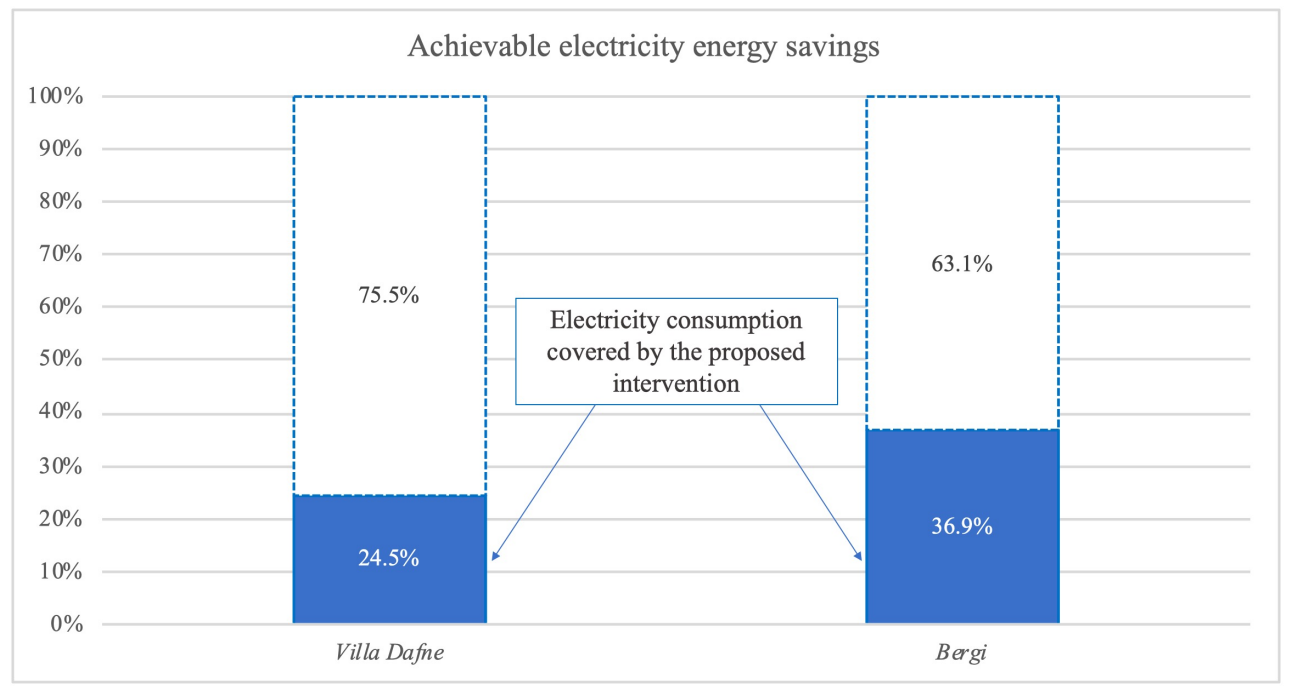

Fig. 2. Achievable energy savings (ES) in terms of percentage of electricity consumption covered by the proposed intervention (data sheet $\mathrm{N}^{\circ}$ ) on annual basis.

The results reported in Figure 2 seem to show how the adoption of a PV system (assessed by means the application of data sheet $\mathrm{N}^{\circ} 7$ ) would improve the energy performances of the considered agritourisms, although not significantly. For Bergi, in fact, it would be possible to cover about one third of the annual electricity consumption, while for Villa Dafne such value decreases to even about one quarter.

These results are not surprising, given the fact that the ARERA technical data sheets were designed for the residential sector and, applying interventions specifically designed for the residential sector to the agritourism context could result quite limiting. In particular, the limits imposed on the UFRs size make the achievable energy savings much lower than those actually obtainable in an agritourism. 
Regarding data sheet $\mathrm{N}^{\circ} 7$, for example, a maximum $k W_{p}$ of $20 \mathrm{~kW}$ is reductive for an agritourism, which usually has wide areas where to install larger photovoltaic systems, and therefore exploit such proposed intervention in a much more productive way. To confirm this, both of the surveyed agritourisms currently have a 100-kW photovoltaic system under design phase.

Nevertheless, the adoption of PV systems, despite being a simple and limited intervention, would address both agritourisms toward a nZEB path, contributing in improving the sustainable performances of the considered sites.

In light of these considerations, to be able to apply data sheet $\mathrm{N}^{\circ} 7$ to an agritourism (or to a structure larger than a residential standard one anyway) it would be more sensible to review the application rule, for instance by imposing a limit, not on the peak power value of the system, but on the maximum percentage of the annual electricity consumption to be covered with photovoltaic so as not to verge on commercial use.

As previously mentioned, the application of data sheet $\mathrm{N}^{\circ} 7$ has been used for demonstration purposes in order to show the proposed approach. Obviously, similar considerations regarding the discrepancies in applying calculation methods designed for the residential sector in wider contexts, such as the agritourism one, could also arise from the application of the other proposed interventions (Table 2) [40].

\section{Conclusions}

The present work started from considerations regarding the possibility of finding a simple method to assess the energy and environmental benefits related to the implementation of some energy efficiency interventions on a given agritourism, also in sight of the possible achievement of a European environmental excellence brand like the EU Ecolabel, or even in the perspective of a broader context/framework, that is a Nearly Zero Energy path.

On purpose, it was decided to use the ARERA technical data sheets since they constitute an official, yet simplified, reference at the Italian national level. The advantage in the use of these technical data sheets lies, indeed, in the fact that they allow to estimate the energy demand reductions, by simply transferring the calculation methods into excel spreadsheets, hence without necessarily going through the building energy simulation.

The application of the considered data sheet to the two surveyed agritourisms, object of the presented application, suggest that the proposed intervention, as recommended by the ARERA, seems to not be consistent with the agritourism context. This outcome could have been expected; in fact, the limit on the characteristics of the photovoltaic system, thought for a residential setting (such as a reference apartment), are not suitable with larger structures. Furthermore, it should also be considered that these data sheets have not been updated in the last few years.

On the basis of the obtained results and of the above-made considerations it appears that, in order to apply the proposed methodology to the agritourism sector (and specifically to the whole Sicilian agritourism building stock), the existing technical data sheets should be adequately updated, or, better yet, some specific ones for the accommodation and catering services should be issued. In fact, a tool like this could not only helping the owners and/or managers of such structures, but would also be useful for the political decisionmakers in order to better define the energy and environmental policies concerning the sector.

In conclusion, the cooperation between public administration, technical experts and researchers working on simple but yet reliable energy saving calculation methodologies, is essential in order to improve the energy and environmental efficiency of the agritourism sector. 
This work was carried out within the research funds provided by the XXXIII Cycle Doctoral Course in Energy and Information Technologies of the University of Palermo.

\section{References}

1. UNWTO Annual Report 2017, United Nations World Tourism Organization (2018).

2. WTTC Report 2017, World Travel and Tourism Council (2018).

3. Filipe Batista e Silva, Mario Alberto Marín Herrera, Kontantín Rosina, Ricardo Ribeiro Barranco, Sergio Freire, Marcello Schiavina, Analysing spatiotemporal patterns of tourism in Europe at high-resolution with conventional and big data sources, Tourism Management 68 (2018), pp. 101-115.

4. Cem Isik, Eyüp Dogan and Serdar Ongan,. Analyzing the Tourism-Energy-Growth Nexus for the Top 10 Most-Visited Countries, Economies 5 (2017), p. 40.

5. Marinela Krstinić Nižić, Zvonimira Šverko Grdić, Andreja Hustić, The Importance of Energy for the Tourism Sector, Academica Turistica, Year 9, No. 2. (2016).

6. European Commission - JRC Science for Policy Report Energy consumption and energy efficiency trends in the EU-28 for the period 2000-2016 (C) European Union (2018).

7. World Energy Balances 2018. International Energy Agency - IEA (2018).

8. Marco Beccali, Maria La Gennusa, Leonardo Lo Coco, Gianfranco Rizzo, An empirical approach for ranking environmental and energy saving measures in the hotel sector, Renewable Energy 34 (2009), pp. 82-90.

9. Maria P. Pablo-Romero, Antonio Sánchez-Braza and Javier Sánchez-Rivas Sustainability, Relationships between Hotel and Restaurant Electricity Consumption and Tourism in 11 European Union Countries, Sustainability 9(11) (2017), p. 2109.

10. Tourism Green Economy and Trade: Trends, Challenges and Opportunities. United Nations Environment Programme, UNEP, (2013), pp. 260-291.

11. A/RES/70/1. General Assembly. Distr.: General 21 October 2015. Transforming our world: the 2030 Agenda for Sustainable Development, United Nations (2015).

12. https://www.un.org/sustainabledevelopment/sustainable-development-goals/.

13. 22.1.2014 COM(2014) 15 final. COMMUNICATION FROM THE COMMISSION TO THE EUROPEAN PARLIAMENT, THE COUNCIL, THE EUROPEAN ECONOMIC AND SOCIAL COMMITTEE AND THE COMMITTEE OF THE REGIONS. A policy framework for climate and energy in the period from 2020 to 2030, European Commission. Brussels (2014).

14. 28.11.2018 COM(2018) 773 final. COMMUNICATION FROM THE COMMISSION TO THE EUROPEAN PARLIAMENT, THE EUROPEAN COUNCIL, THE COUNCIL, THE EUROPEAN ECONOMIC AND SOCIAL COMMITTEE, THE COMMITTEE OF THE REGIONS AND THE EUROPEAN INVESTMENT BANK. A Clean Planet for all A European strategic long-term vision for a prosperous, modern, competitive and climate neutral economy, European Commission. Brussels (2018).

15. ITALY'S NATIONAL ENERGY STRATEGY, Ministero dello Sviluppo Economico; Ministero dell'Ambiente e della tutela del Territorio e del Mare, (2017).

16. UNWTO, A Roadmap for Celebrating Togerther. World Tourism Organization, (2016).

17. Saarinen, J., Rogerson, C.M., Tourism and the millennium development goals: perspectives beyond 2015, Tour. Geogr. 16 (2013), pp. 23-30.

18. ONT Report. Agenzia Nazionale Turismo Italia, Ufficio Studi ENIT, Turismo in Cifre 2018/2019, ONT - Italian National Tourism Observatory - elaboration on WTTC World Travel \& Tourism Council - data, (2019). 
19. Y. Ali, M. Ciaschini, R. Pretaroli, F. Severini, C. Socci, Economic relevance of Tourism industry: the Italian case. Quaderno di Dipartimento n. 72 Università degli Studi di Macerata, Dipartimento di Economia e Diritto, (2014).

20. ISPRA Report (2018) (https://annuario.isprambiente.it/ada/macro/28).

21. Francesca D’Alessandro, Green Building for a Green Tourism. A new model of ecofriendly agritourism, Agriculture and Agricultural Science Procedia 8 (2016), pp. 201210.

22. Luigi Mastronardi, Vincenzo Giaccio, Agostino Giannelli, Alfonso Scardera, Agriturismo e sostenibilità ambientale, Primi risultati di un'analisi aziendale, Agriregionieuropa anno 11, $\mathrm{n}^{\circ} 40,(2015)$.

23. Maria José Palma Lampreia Dos Santos, Nawaz Ahmad, Sustainability of European agricultural holdings, Journal of the Saudi Society of Agricultural Sciences, (2020), In Press, Journal Pre-proof.

24. Giorgia Peri, Esther Sanyé-Mengual, Joan Rieradevall, Giuseppina Ciulla and Gianfranco Rizzo, Proposal of a New Operative Brand for Environmentally Labelling Agritourism: Embodying Tourism, Buildings and Transportation Requirements, World Applied Sciences Journal 32(9) (2014), pp. 1764-1774.

25. Giorgia Peri, Gianfranco Rizzo, The overall classification of residential buildings: Possible role of tourist EU Ecolabel award scheme, Building and Environment 56 (2012), pp. 151-161.

26. Li Zhu, Binghua Wang, Yong Sun, Multi-objective optimization for energy consumption, daylighting and thermal comfort performance of rural tourism buildings in north China, Building and Environment 176 (2020), 106841.

27. European Commission JRC Scientific and Policy Report on Best Environmental Management Practice in the Tourism Sector D. Styles, H. Schönberger, J. L. Galvez Martos (C) European Union, (2013).

28. Regulation (EC) No 1221/2009 of the European Parliament and of the Council of 25 November 2009 on the voluntary participation by organisations in a Community ecomanagement and audit scheme (EMAS), OJ L 342, 22.12.2009, (2009).

29. COMMISSION DECISION (EU) 2017/175 of 25 January 2017 on establishing EU Ecolabel criteria for tourist accommodation, (2017).

30. Technical Data Sheets ARERA - Autorità di Regolazione per Energia Reti e Ambiente (https://www.arera.it/it/).

31. Javier Polanco González, Charles Yousif, Prioritising energy efficiency measures to achieve a zero net-energy hotel on the island of Gozo in the central Mediterranean, Energy Procedia 83 (2015), pp. 50-59.

32. Theocharis Tsoutsos, Stavroula Tournaki, Carmen Avellaner de Santos, Roberto Vercellotti, Nearly Zero Energy Buildings Application in Mediterranean hotels, Energy Procedia 42 (2013), pp. 230-238.

33. Tiziana Buso, Cristina Becchio, Stefano P. Corgnati, NZEB, cost- and comfort-optimal retrofit solutions for an Italian Reference Hotel, Energy Procedia 140 (2017), pp. 217230.

34. Vincenzo Bianco, Federico Scarpa, Luca A. Tagliafico, Modeling energy consumption and efficiency measures in the Italian hotel sector, Energy and Buildings 149 (2017), pp. 329-338.

35. Legge 20 febbraio 2006, n. 96 "Disciplina dell'agriturismo" pubblicata nella Gazzetta Ufficiale n. 63 del 16 marzo 2006, (2006).

36. REGIONE SICILIA - LEGGE REGIONALE 9 giugno 1994, n. 25 G.U.R.S. 14 giugno 1994, n. 30. Norme sull'agriturismo. TESTO COORDINATO (aggiornato al D.A. Agricoltura 14 giugno 1997), (1997). 
37. GAZZETTA UFFICIALE DELLA REGIONE SICILIANA - 1 mar 2010 - PARTE I n. 10. LEGGE 26 febbraio 2010, n. 3. - Disciplina dell'agriturismo in Sicilia, (2010).

38. REGULATION (EC) No 66/2010 OF THE EUROPEAN PARLIAMENT AND OF THE COUNCIL of 25 November 2009 on the EU Ecolabel, (2010).

39. https://ec.europa.eu/environment/ecolabel/.

40. Cirrincione, L., La Gennusa, M., Peri, G., Rizzo, G., Scaccianoce, G. Towards Nearly Zero Energy and Environmentally Sustainable Agritourisms: The Effectiveness of the Application of the European Ecolabel Brand. Applied Sciences 10 (2020), 5741. 